\title{
Инсоляция помещений как средство ограничения распространения COVID-19, гриппа и ОРВИ в городской среде
}

\author{
И.А.Шмаров, НИИСФ РААСН, Москва \\ В.А.Земцов, НИИСФ РААСН, Москва \\ А.С.Гуськов, Роспотребнадзор, Москва \\ Л.В.Бражникова, НИИСФ РААСН, Москва
}

Инсоляция помещений жилых, общественных зданий и прилегающих территорий регулирует поступление естественного ультрафиолетового излучения и является важным фактором, который необходимо учитывать при проектировании городской застройки. Она способствует ограничению распространения вирусных и бактериальных заболеваний, передающихся как воздушно-капельным аэрозольным путём, так и через общедоступные поверхности помещений. В статье проанализировано современное состояние нормирования и расчёта продолжительности инсоляции в национальных и зарубежных нормах. Показано, что ультрафиолетовый свет поступает в помещения через современное энергосберегающее остекление. Сделан вывод о необходимости сохранения данного фактора в обеспечении безопасности зданий и сооружений.

Ключевые слова: продолжительность инсоляции, инсоляционный график, солнечная карта, плотность застройки.

Insolation of Premises as a Means of Limiting the Spread of COVID-19, Influenza, and Acute Respiratory Viral Infections in an Urban Environment

I.A.Shmarov, NIISF RAACS, Moscow

V.A.Zemtsov, NIISF RAACS, Moscow

A.S.Guskov, Rospotrebnadzor, Moscow

L.V.Brazhnikova, NIISF RAACS, Moscow

The insolation of premises in residential, public buildings, and adjacent areas regulates the flow of natural ultraviolet radiation and is an important factor that must be taken into account in the design of urban development. It helps tolimit the spread of viral and bacterial diseases transmitted both by airborne aerosol droplets and through public surfaces of premises. The article analyzes the current state of standardization and calculation of the sun duration in national and foreign standards. It is shown that ultravioletlight enters rooms through modern energy-saving glazing. It is concluded that it is necessary to preserve this factor in ensuring the safety of buildings and structures.

Keywords: sun duration (insolation), insolation graph, solar map building density.

0 благоприятном воздействии солнечного излучения на здоровье человека известно давно. Еще в древности медики заметили, что «в жилище, где не бывает солнца, часто быва- ет врач». Санирующим эффектом воздействия на бактерии, вирусы и патогенную микрофлору (споры грибов, плесени) обладает присутствующее в спектре солнечного света ультрафиолетовое излучение.

Недавние исследования Национального центра анализа биозащиты и контрмер, входящего в состав Национального института биозащиты Баттелля Министерства внутренней безопасности США [1], показали инактивирующее влияние солнечного излучения на коронавирус SARS-CoV-2, вызывающий коронавирусную болезнь Covid-19. В работе исследовалось влияние солнечных лучей в условиях возможного распространения этого вируса: через аэрозоли и поверхности.

Согласно проведённым исследованиям средние скорости гибели вирусов SARS-CoV-2 в смоделированной слюне при смоделированных мощностях солнечного света, характерных для поздней зимы/ранней осени и лета, составляли 0,121 \pm 0,017 мин ${ }^{-1}$ (гибель 90\% вирусов за 19 мин) и 0,306 \pm 0,097 мин $^{-1}$ (гибель $90 \%$ вирусов за 8 мин), соответственно. Средняя скорость гибели вирусов без смоделированного солнечного света по всем уровням относительной влажности составляла $0,008 \pm 0,011$ мин $^{-1}$ (гибель 90\% вирусов за 286 мин). Эти результаты позволяют полагать, что возможность аэрозольного распространения SARS-CoV-2 зависит от условий окружающей среды, в частности от солнечного света.

Аналогичное воздействие солнечного света было отмечено и для вирусов, помещённых на поверхности. Исследователи отметили, что смоделированный солнечный свет был способен быстро инактивировать SARS-CoV-2 на образцах из нержавеющей стали. Результаты показали, что 90\% инфекционного вируса инактивировали всего за 6,8 минуты в растворе слюны и за 14,3 минуты в культуральной среде. Необходимый для этого смоделированный солнечный свет по спектру и мощности был такой, как солнечный свет в летнее солнцестояние (22 июня) в ясный день, на 40-ой северной широте на уровне моря. Подобная инактивация также наблюдалась с более низкой скоростью, когда мощности солнечного света были ниже, то есть времени для гибели вирусов требовалось больше. Гибель вирусов происходит от ультрафиолетовой части солнечного излучения УФ-В и УФ-А, поскольку УФ-С до поверхности земли практически не доходит.

В современной практике строительства бактерицидный и антивирусный факторы воздействия среды, обеспечивающие профилактику заболеваний, известны как инсоляция (insolation), или солнечное освещение (sun duration). 
Таблица 1. Требования к продолжительности инсоляции жилища

\begin{tabular}{|c|c|c|c|c|}
\hline \multirow[b]{2}{*}{ Страна } & \multirow{2}{*}{$\begin{array}{c}\text { Диапазон } \\
\text { географических } \\
\text { широт }\end{array}$} & \multicolumn{3}{|c|}{ Нормы продолжительности инсоляции } \\
\hline & & Период года & $\begin{array}{l}\text { Расчетный } \\
\text { день }\end{array}$ & $\begin{array}{c}\text { Продолжительность } \\
\text { инсоляции }\end{array}$ \\
\hline $\begin{array}{l}\text { Документ ООН - } \\
\text { Компендиум ЕЭК [11] }\end{array}$ & - & с 20 марта по 22 сент. & - & 24 \\
\hline \multirow{5}{*}{ Россия [12-13] } & севернее $58^{\circ}$ с.ш. & с 22 апр. по 22 авг. & 22 авг. & 2 ч 30 мин \\
\hline & севернее $58^{\circ}$ с.ш. & с 22 апр. по 22 авг. & 22 авг. & 24 \\
\hline & $48^{\circ}-58^{\circ}$ С.ш. & с 22 апр. по 22 авг. & 22 авг. & 2 ч ( в одной комнате) \\
\hline & $48^{\circ}-58^{\circ} \mathrm{C} . ш$. & с 22 апр. по 22 авг. & 22 авг. & $\begin{array}{c}1 \text { ч } 30 \text { мин } \\
\text { (в каждой из двух комнат) }\end{array}$ \\
\hline & южнее $48^{\circ}$ с.ш. & с 22 февр. по 22 окт. & 22 февр. & 1 ч 30 мин \\
\hline \multirow{2}{*}{ Великобритания [17] } & \multirow{2}{*}{ 49,6 - 60,5ㄷ.ш. } & с 21 марта по 21 сент. & 21 марта & $\begin{array}{c}25 \% \text { от возможного вре- } \\
\text { мени инсоляции в год }\end{array}$ \\
\hline & & с 21 сент. по 21 марта & - & $\begin{array}{c}5 \% \text { от возможного времени. } \\
\text { инсоляции в год }\end{array}$ \\
\hline Евросоюз [14] & $47^{\circ}-55^{\circ}$ с.ш. & с 21 марта по 21 сент. & 21 марта & 1 ч 30 мин \\
\hline \multirow[t]{2}{*}{ Германия [15-16] } & \multirow[b]{2}{*}{$47^{\circ}-55^{\circ}$ С.ш } & с 21 марта по 21 сент. & 21 марта & 4 ч \\
\hline & & $\begin{array}{l}\text { дополнительный } \\
\text { зимний критерий }\end{array}$ & 17 янв. & 14 \\
\hline Франция [18-19] & $39^{\circ}-54^{\circ}$ С.ш. & $\begin{array}{c}\text { с } 13 \text { марта по } 28 \text { сент. } \\
\text { (200 дней) }\end{array}$ & - & 24 \\
\hline Италия [7] & $37^{\circ}-47^{\circ}$ с.ш. & с 19 февр. по 21 окт. & - & 24 \\
\hline Швеция [20--21] & $55^{\circ}-69^{\circ}$ с.ш. & с 20 марта по 22 сент. & $\begin{array}{l}20 \text { марта и } \\
22 \text { сент. }\end{array}$ & $\begin{array}{l}5 \text { ч (в период с } 9 \text { утра до } 5 \\
\text { вечера в одной из комнат) }\end{array}$ \\
\hline \multirow{2}{*}{ Нидерланды [7] } & \multirow{2}{*}{$51^{\circ}-53^{\circ}$ с.ш. } & с 19 февр. по 21 окт. & - & 24 \\
\hline & & с 21 янв. по 22 нояб. & - & 34 \\
\hline Чехия [22-23] & $48,3^{\circ}-51^{\circ}$ C.Ш. & с 10 февр. по 21 марта & 1 марта & $\begin{array}{c}1 \text { ч } 30 \text { мин (начало при } \\
\text { высоте стояния солнца } 5^{0}\end{array}$ \\
\hline Словакия [24-26] & 48,3ำ - 48,9 с.ш. & $\begin{array}{l}01 \text { марта по } \\
13 \text { окт. }\end{array}$ & - & 1 ч 30 мин \\
\hline \multirow{3}{*}{ Словения [27-28] } & \multirow{3}{*}{$\begin{array}{c}45,2^{\circ}-46,8^{\circ} \\
\text { с.ш. }\end{array}$} & 21 декабря. & 21 дек. & 24 \\
\hline & & с 21 марта по -23 сент. & 21 март. & 4 ч \\
\hline & & 21 июля & 22 февр. & 64 \\
\hline Польша [29] & $49^{\circ}-54^{\circ}$ с.ш. & с 21 марта по 21 сент & $\begin{array}{l}21 \text { марта; } \\
21 \text { сент. }\end{array}$ & $1 ч 30$ мин \\
\hline Эстония [30-31] & 57,7 - 59,4 с.ш. & с 22 апр. по 22 авг. & - & 34 \\
\hline Китай [32-36] & $21^{\circ}-53,3^{\circ}$ c.ш. & - & 11-13 янв. & 24 \\
\hline \multirow{2}{*}{ Монголия [37] } & $\begin{array}{l}\text { севернее } 48^{\circ} \\
\text { с.ш. }\end{array}$ & с 22 марта по 22 сент. & $\begin{array}{l}22 \text { марта; } \\
22 \text { сент. }\end{array}$ & 2 ч 30 мин \\
\hline & южнее $48^{\circ}$ с.ш. & с 22 февр. по 22 окт. & $\begin{array}{l}22 \text { февр.; } \\
22 \text { окт. }\end{array}$ & 24 \\
\hline Беларусь [38] & - & с 22 марта по 22 сент. & $\begin{array}{l}22 \text { марта; } \\
22 \text { сент. }\end{array}$ & 24 \\
\hline Казахстан [39] & $48^{\circ}-58^{\circ} \mathrm{C} . ш$. & с 22 марта по 22 сент. & $\begin{array}{l}22 \text { марта; } \\
22 \text { сент. }\end{array}$ & 2 ч 30 мин \\
\hline Украина [40] & - & с 22 марта по 22 сент. & $\begin{array}{l}22 \text { марта; } \\
22 \text { сент. }\end{array}$ & 2 ч 30 мин \\
\hline
\end{tabular}

Примечания: ${ }^{1}$ - учитываются погодные условия. 
В ограниченном пространстве заражение человека туберкулёзом органов дыхания, гриппом, острыми респираторновирусными инфекциями и многими другими заболеваниями происходит воздушно-капельным путём. Согласно приведённым данным в солнечном свете, поступающем в помещения, культура бактерий туберкулёза погибает через 1,5 часа [2; 3, с. 84], культура бактерий золотистого стафилококка - через 1,5 часа [4, с. 7]. Нестойки к солнечному излучению вирусы гриппа [2]. В [4, с. 7] выявлена зависимость заболевания острыми респираторными вирусными инфекциями от плотности городской застройки. В работах [5; 6] было отмечено положительное действие инсоляции на психоэмоциональное состояние испытуемых и необходимость её учета при проектировании зданий.

Сопоставление графиков зависимости числа зараженных SARS-CoV-2 по месяцам с интенсивностью поступления в это же время естественного ультрафиолета в Москве показало, что минимальное заражение происходило в летние месяцы, когда поступление естественного ультрафиолета максимально.

Таблица 2. Требования к продолжительности инсоляции помещений общественных зданий

\begin{tabular}{|c|c|c|c|c|}
\hline \multirow[b]{2}{*}{ Страна } & \multirow{2}{*}{$\begin{array}{c}\text { Диапазон } \\
\text { географических } \\
\text { широт }\end{array}$} & \multicolumn{3}{|c|}{ Нормы продолжительности инсоляции } \\
\hline & & Период года & $\begin{array}{c}\text { Расчётный } \\
\text { день }\end{array}$ & $\begin{array}{c}\text { Продолжительность } \\
\text { инсоляции }\end{array}$ \\
\hline \multirow{3}{*}{ Россия [12-13] } & $\begin{array}{l}\text { севернее } 58^{\circ} \\
\text { с.ш. }\end{array}$ & с 22 апр. по 22 авг. & 22 авг. & 2430 мин \\
\hline & $48^{\circ}-58^{\circ}$ с.ш. & с 22 марта по -22 сент. & 22 сент. & 24 \\
\hline & южнее $48^{\circ}$ с.ш. & с 22 февр. по 22 окт. & 22 февр. & 1 ч 30 мин \\
\hline \multirow{2}{*}{$\begin{array}{c}\text { Великобритания } \\
\text { [17] }\end{array}$} & \multirow{2}{*}{$\begin{array}{c}49,6^{\circ}-60,5^{\circ} \\
\text { с.ш. }\end{array}$} & с 21 марта по 21 сент. & 21 марта & $\begin{array}{c}25 \% \text { от возм. врем. } \\
\text { инсоляции в год }\end{array}$ \\
\hline & & с 21 сент. по 21 марта & - & $\begin{array}{l}\text { 5\% от возм. врем. } \\
\text { инсоляции в год }\end{array}$ \\
\hline Евросоюз [14] & $55^{\circ}-69^{\circ}$ с.ш. & - & $\begin{array}{c}20 \text { марта и } 22 \\
\text { сент. }\end{array}$ & 54 \\
\hline \multirow{2}{*}{ Китай [32-36] } & \multirow{2}{*}{$21^{\circ}-53,3^{\circ}$ с.ш. } & - & 1113 янв. & 24 \\
\hline & & круглогодично & 21 дек. & 24 \\
\hline \multirow{2}{*}{ Монголия [37] } & $\begin{array}{c}\text { севернее } 48^{\circ} \\
\text { с.ш. }\end{array}$ & с 22 марта по 22 сент. & $\begin{array}{l}22 \text { марта; } \\
22 \text { сент. }\end{array}$ & 34 \\
\hline & южнее $48^{\circ}$ с.ш. & с 22 февр. по 22 окт. & $\begin{array}{l}22 \text { февер.; } \\
22 \text { окт. }\end{array}$ & 34 \\
\hline Беларусь [38] & - & с 22 марта по 22 сент. & $\begin{array}{l}22 \text { марта; } \\
22 \text { сент. }\end{array}$ & 34 \\
\hline Казахстан [39] & - & с 22 марта по 22 сент. & $\begin{array}{l}22 \text { марта; } \\
22 \text { сент. }\end{array}$ & 34 \\
\hline Украина [40] & - & с 22 марта по 22 сент. & $\begin{array}{l}22 \text { марта; } \\
22 \text { сент. }\end{array}$ & 34 \\
\hline
\end{tabular}

Таблица 3. Требования к продолжительности инсоляции детских площадок на территории застройки

\begin{tabular}{|c|c|c|c|c|}
\hline \multirow[b]{2}{*}{ Страна } & \multirow[b]{2}{*}{$\begin{array}{c}\text { Диапазон } \\
\text { географических } \\
\text { широт }\end{array}$} & \multicolumn{3}{|c|}{ Нормы продолжительности инсоляции } \\
\hline & & Период года & $\begin{array}{c}\text { Расчетный } \\
\text { день }\end{array}$ & $\begin{array}{l}\text { Продолжи- } \\
\text { тельность } \\
\text { инсоляции }\end{array}$ \\
\hline \multirow{3}{*}{ Россия [12-13] } & $\begin{array}{c}\text { севернее } \\
58^{\circ} \text { с.ш. }\end{array}$ & с 22 апр. по 22 авг. & 22 авг. & 34 \\
\hline & $48^{\circ}-58^{\circ}$ с.ш. & с 22 марта по 22 сент. & 22 сент. & 34 \\
\hline & южнее $48^{\circ}$ с.ш. & с 22 февр. по 22 окт. & 22 февр. & 34 \\
\hline Китай [32-36] & $21^{\circ}-53,3^{\circ}$ с.ш. & - & 21 дек. & 24 \\
\hline \multirow{2}{*}{ Монголия [37] } & $\begin{array}{c}\text { севернее } \\
48^{\circ} \text { с.ш. }\end{array}$ & с 22 марта по 22 сент. & $\begin{array}{l}22 \text { марта; } \\
22 \text { сент. }\end{array}$ & 2 ч 30 мин \\
\hline & южнее $48^{\circ}$ с.ш. & с 22 февр. по 22 окт. & $\begin{array}{l}22 \text { февр.; } \\
22 \text { окт. }\end{array}$ & 24 \\
\hline Беларусь [38] & - & с 22 марта по 22 сент. & $\begin{array}{l}22 \text { марта; } \\
22 \text { сент. }\end{array}$ & 2 ч 30 мин \\
\hline Казахстан [39] & - & с 22 марта по 22 сент. & $\begin{array}{l}22 \text { марта; } \\
22 \text { сент. }\end{array}$ & 34 \\
\hline Украина [40] & - & с 22 марта по 22 сент. & $\begin{array}{l}22 \text { марта; } \\
22 \text { сент. }\end{array}$ & 34 \\
\hline
\end{tabular}


Таблица 4. Основные документы, использованные для нормирования и расчёта инсоляции в различных странах

\begin{tabular}{|c|c|}
\hline Страна & Основные нормативные документы \\
\hline Россия & 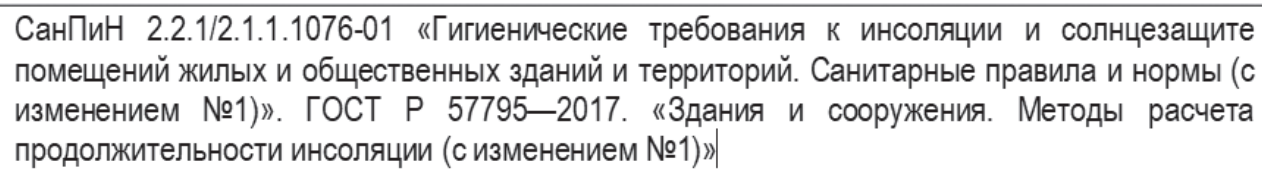 \\
\hline Евросоюз & EN 17037:2018. Естественное освещение зданий \\
\hline Германия & $\begin{array}{l}\text { DIN 5034-1: } 2011 \text { Tageslicht in Innenraumen. Teil 1: Allgemeine Anforderungen. - Berlin, } \\
\text { Deutsches Institut für Normung e.V., 2011. DIN 5034-2: } 1985 \text { Tageslicht in Innenräumen. } \\
\text { Grundlagen - Berlin, Deutsches Institut für Normung e.V., } 1985\end{array}$ \\
\hline Великобритания & BS 8206-2:2008. Lighting for buildings. Part 2 - London, BSI, 2008. \\
\hline Франция & $\begin{array}{l}\text { Градостроительный кодекс Франции R 111-17 (Art R 111-17 Town planning code). Декрет } \\
\text { Франции 73-1023 - } 8 \text { февраля } 1973 \text { (Decret 73-1023 - 8th of February 1973). }\end{array}$ \\
\hline Италия & $\begin{array}{l}\text { Протокол оценки экологической устойчивости для принятия регионами в своих } \\
\text { строительных нормах. Региональные и коммунальные кодексы }\end{array}$ \\
\hline Швеция & $\begin{array}{l}\text { Собрание уставов Национального совета по жилищному строительству и планированию - } \\
\text { публикация Solklar (Boverkets författningssamling - publication Solklart), 1991; Сборник } \\
\text { законодательных актов Национального совета по жилищному хозяйству, строительству и } \\
\text { планированию - Постановление о строительстве (Boverkets författningssamling - building } \\
\text { regulation BFS 2014:3; H255)- The handbook "To see, hear and breathe in school", } 1996\end{array}$ \\
\hline Нидерланды & Some big cities use the so-called 'TNO standard \\
\hline Чехия & $\begin{array}{l}\text { Постановление № 268/2009 о технических требованиях для зданий. (Чехия) (Regulation } \\
\text { No. 268/2009 about technical requirements for buildings). Стандарт Чехи ČSN } 73 \\
\text { 4301:2004. Жилые здания. (ČSN } 73 \text { 4301:2004. Obytné budovy) }\end{array}$ \\
\hline Словакия & $\begin{array}{l}\text { Постановление № 259/2008 Министерства здравоохранения Словацкой Республики. } \\
\text { Регламент № 532/2002 Министерства окружающей среды Словацкой Республики. } \\
\text { Стандарт: STN 734301:2005 (Жилые постройки) }\end{array}$ \\
\hline Словения & $\begin{array}{l}\text { Правила минимальных технических требований при строительстве жилых домов - } 2005 \text {. } \\
\text { TSG-1-004:2010 Техническое руководство. Эффективное использование энергии. } \\
\text { Myниципальные правила. (Rules on minimum technical requirements for the construction of } \\
\text { residential buildings- 2005. TSG-1-004:2010 Technical guideline. Efficient use of energy; } \\
\text { Municipalities rules) }\end{array}$ \\
\hline Польша & $\begin{array}{l}\text { Постановление № 620/2002 Министерства инфраструктуры Польши по техническим } \\
\text { требованиям, которым должны удовлетворять здания и их размещение при } \\
\text { строительстве (Regulation No. } 620 / 2002 \text { of the Ministry of Infrastructure on the technical } \\
\text { requirements to be met by buildings and their placement.) }\end{array}$ \\
\hline Эстония & $\begin{array}{l}\text { RT I: } 2002 \text { Закон о строительстве (Строительный кодекс)- (Ehitusseadus (Building } \\
\text { Code).Стандарт EVS 894:2008+A1:2010. Освещение жилых и офисных помещений } \\
\text { (Standard: EVS 894:2008+A1:2010. Lighting for residential and office premises) }\end{array}$ \\
\hline Китай & $\begin{array}{l}\text { Технические стандарты инсоляции зданий провинций Хубэй, Чжэцзян, Хэнань, Гирин, } \\
\text { Цзенсу. (湖北省建筑日照分析技术规范 }\end{array}$ \\
\hline Монголия & $\begin{array}{l}\text { БНбД 23-02-08. «Байгалийн ба зохиомол гэрэлтуулэг» - 08. - Улаанбаатар хот, } 2008 \text { он. } \\
\text { БНбД 23-04-07 «Орон сууц, олон нийтийн барилга, сууцны барилгажилтын бусийн нарны } \\
\text { тусгалын (ээвэрлэлтийн) хангамж». - Улаанбаатар хот, 2007он }\end{array}$ \\
\hline Беларусь & $\begin{array}{l}\text { Санитарные правила и нормы. Гигиенические требования обеспечения инсоляцией жилых } \\
\text { и общественных зданий и территорий жилой застройки. Постановление Министерства } \\
\text { здравоохранения Республики Беларусь } 28 \text { апр. } 2008 \text { № } 80 \text { - Минск. }-10 \text { с. }\end{array}$ \\
\hline Казахстан & $\begin{array}{l}\text { Санитарно-эпидемиологические требования к административным и жилым зданиям. } \\
\text { Приказ Министра здравоохранения Республики Казахстан от } 26 \text { октября } 2018 \text { года № қР } \\
\text { дСМ-29 }\end{array}$ \\
\hline Украина & $\begin{array}{l}\text { Державні санітарні правила планування та забудови населених пунктів, Затверджено } \\
\text { наказом Міністерства охорони здоров'я України від } 19 \text { червня } 1996 \text { р. № 173. Будинки і } \\
\text { споруди. Настанова з розрахунку інсоляції об'єктів цивільного призначения. ДСТУ Н Б } \\
\text { В.2.2-27:2010. / Минрегіонбуд України. - Киев: Укрархбудінформ, } 2010\end{array}$ \\
\hline
\end{tabular}


Согласно документу 00Н - ЕСЕ/НВР8ё1 «Компендиум Европейской экономической комиссии (ЕЭК), включающий образцы положений для строительных правил» [11], национальные нормы должны содержать нормативы продолжительности инсоляции.

В основе современных норм инсоляции России [12-13] лежит инактивация бактерий золотистого стафилококка, живущих на поверхностях помещений жилых и общественных зданий.

В Евросоюзе вышел новый стандарт ЕN 13037:2018 «Естественное освещение» [14], содержащий нормы продолжительности инсоляции, согласно которому минимальная продолжительность инсоляции составляет 1,5 часа. Сохраняются и национальные нормы продолжительности инсоляции [15-40].

Нормируемый в годовом цикле период инсоляции (в месяцах) и продолжительность инсоляции в национальных нормах зависят от географической широты расположения страны. Чем меньше значение географической широты, тем более продолжительный период года определяется нормами инсоляции, и чем севернее расположено государство (больше географическая широта), тем больше нормируемая продолжительность инсоляции. В таблицах 1-3 представлены данные о периоде и продолжительности инсоляции для различных стран при нормировании инсоляции в жилых, общественных зданиях и территориях, соответственно. Межгосударственные и национальные документы, использованные для анализа нормирования и расчёта инсоляции, приведены в таблице 4.

Кроме того, как следует из таблиц 1-3, для нормирования инсоляции установлены периоды с весны по осень, но по российским нормам расчет её ведется только на расчётные дни. Норма инсоляции в летние месяцы может не выполняться из-за наличия вертикальных затеняющих углов, ограничивающих балконами и лоджиями. Однако в эти месяцы в помещения поступает достаточно ультрафиолетового излучения, рассеянного в атмосфере.

В этом состоит основное отличие норм инсоляции России от норм инсоляции Евросоюза, ЕврАзЭС и Украины, которые требуют расчёта и наличия инсоляции на весь период с весны по осень, что в результате приводит к обеднению архитектурных фасадных решений.

Важным фактором для поступления естественного ультрафиолетового излучения в помещения является качество используемых в стеклопакетах стёкол. Надо отметить, что современная промышленность выпускает эффективные стекла, обладающие высоким коэффициентом пропускания ультрафиолета. Экспериментальные исследования, проведённые в КазГАСУ [8] и НИИСФ РААСН [9-10] показали, что строительное энергосберегающее стекло с низкоэмиссионным покрытием ограничивает пропускание теплового излучения, но пропускает видимое и ультрафиолетовое излучение.

Стёкла, применяемые в оконных блоках, в том числе с низкоэмиссионными покрытиями, имеют следующие коэффициенты пропускания ультрафиолетового излучения:

- бесцветное стекло без покрытия - 57,9...81,8\%;

- бесцветное стекло с низкоэмиссионным покрытием $30,8 . .52 \%$.

В таблице 5 приведены марки стёкол с коэффициентами пропускания ультрафиолетовых лучей и коэффициентами пропускания лучей видимой части спектра.

Нормы продолжительности инсоляции нельзя рассматривать в отрыве от методики её расчёта. Критическим вопросом является учёт (не учёт) горизонтальных и вертикальных теневых углов. Если теневые углы не учитываются, то нормативная этажность и плотность застройки повышаются. Имеется и обратная ситуация, когда в методику закладывают большие фиксированные теневые углы. В этом случае нормативная этажность и плотность застройки снижаются.

Основными методами расчёта продолжительности инсоляции являются:

- инсоляционные графики, построенные для географической широты района строительства;

- солнечные карты для географической широты района строительства;

Таблица 5. Коэффициенты пропускания ультрафиолетового и видимого излучения современными строительными стёклами

\begin{tabular}{|c|c|c|}
\hline Наименование образца стекла & $\begin{array}{c}\text { Коэффициент } \\
\text { пропускания } \\
\text { ультрафииолетового } \\
\text { излучения \% }\end{array}$ & $\begin{array}{c}\text { Коэффициент } \\
\text { пропускания в видимой } \\
\text { области, \% }\end{array}$ \\
\hline \multicolumn{2}{|c|}{ Стёкла без покрытий } \\
\hline $\begin{array}{c}\text { Стекло без покрытия Pilkington float 4 мм (для } \\
\text { сравнения) }\end{array}$ & 57,9 & 88,6 \\
\hline $\begin{array}{c}\text { Стекло без покрытия Planibel ClearVision 6 мм } \\
\text { (для сравнения) }\end{array}$ & 81,8 & 91,13 \\
\hline Стёкла с низкоэмиссионными покрытиями \\
\hline \multicolumn{2}{|c|}{ Стёкла с солнцезащитными покрытиями } \\
\hline \multicolumn{2}{|c|}{ СlimaGuard Titan (3 обр.) } & 75,9 \\
\hline StopSol Phoenix clear 4 мм(1 обр.) & 44,7 & 62,6 \\
\hline StopSol Phoenix clear 6 мм(1 обр.) & 38,6 & 65,0 \\
\hline
\end{tabular}


Таблица 6. Основные графические методы расчета инсоляции

\begin{tabular}{|c|c|c|}
\hline Страна, документ & $\begin{array}{l}\text { Наименование } \\
\text { методик расчета }\end{array}$ & Графический вид методик \\
\hline \multirow{2}{*}{$\begin{array}{c}\text { Россия, } \\
\text { гост Р 57795-2017. } \\
\text { Здания и сооружения. } \\
\text { Методы расчета про- } \\
\text { должительности инсо- } \\
\text { ляции (с изменением } \\
\text { №1) [42-43] }\end{array}$} & $\begin{array}{c}\text { Инсографики для географической } \\
\text { широты места строительства } \\
\text { с интервалом от } \pm 0,5 \text { до } \pm 2,50\end{array}$ & (1) \\
\hline & $\begin{array}{c}\text { Солнечные карты для } \\
\text { географической широты места } \\
\text { строительства } \\
\text { с интервалом } \\
\text { от } \pm 0,5 \text { до } \pm 2,50\end{array}$ & 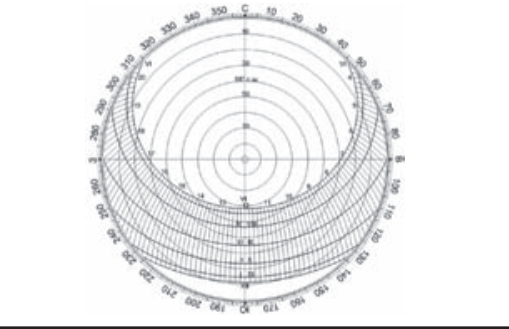 \\
\hline \multirow{2}{*}{$\begin{array}{c}\text { Евросоюз, } \\
\text { EN 17037:2018. } \\
\text { Естественное освеще- } \\
\text { ние зданий [10] }\end{array}$} & $\begin{array}{l}\text { Солнечные карты для } \\
\text { географической широты места } \\
\text { строительства }\end{array}$ & 然 \\
\hline & $\begin{array}{c}\text { Графики для определения продол- } \\
\text { жительности инсоляции при помо- } \\
\text { щи круговой схемы траектории дви- } \\
\text { жения солнца для географической } \\
\text { широты места строительства }\end{array}$ & " \\
\hline $\begin{array}{c}\text { Великобритания, } \\
\text { BS 8206-2:2008 - Part } \\
2 \text { \{13] }\end{array}$ & $\begin{array}{l}\text { Солнечные карты для географиче- } \\
\text { ской широты места строительства }\end{array}$ & \\
\hline \multirow[b]{2}{*}{$\begin{array}{c}\text { Украина, } \\
\text { ДСтУ-Н Б В.2.2-27-2010 } \\
\text { [37] }\end{array}$} & $\begin{array}{l}\text { Инсографики для географической } \\
\text { широты с интервалом широты } 10\end{array}$ & \\
\hline & $\begin{array}{c}\text { Солнечные карты на каждую } \\
\text { географическую широту } \\
\text { с интервалом широты } 10\end{array}$ & \\
\hline
\end{tabular}


- аналитические методы расчёта по формулам;

- программные средства, привязанные к национальным нормам.

Наиболее удобными для применения являются инсоляционные графики. Оптимальным является вариант перенесения инсоляционной линейки в программный комплекс «Autocad» с возможностью перемещения их по генплану застройки. Этот способ давно используют проектные институты. Он позволяют производить расчёт продолжительности инсоляции на расчётный день года, установленный в нормах.

Солнечные карты позволяют рассчитывать продолжительность инсоляции на любой месяц года и пригодны для расчёта солнцезащитных устройств, поскольку позволяют определить период, в течение которого солнцезащитное устройство оказывает затеняющее действие.

Программные средства обладают максимальной точностью, но требуют больших трудозатрат на ввод исходных данных по застройке, проектируемым и существующим зданиям.

Согласно гигиеническим требованиям к инсоляции и солнцезащите помещений жилых и общественных зданий и территорий расчёт продолжительности инсоляции выполняется по графикам с учётом географической широты территории.

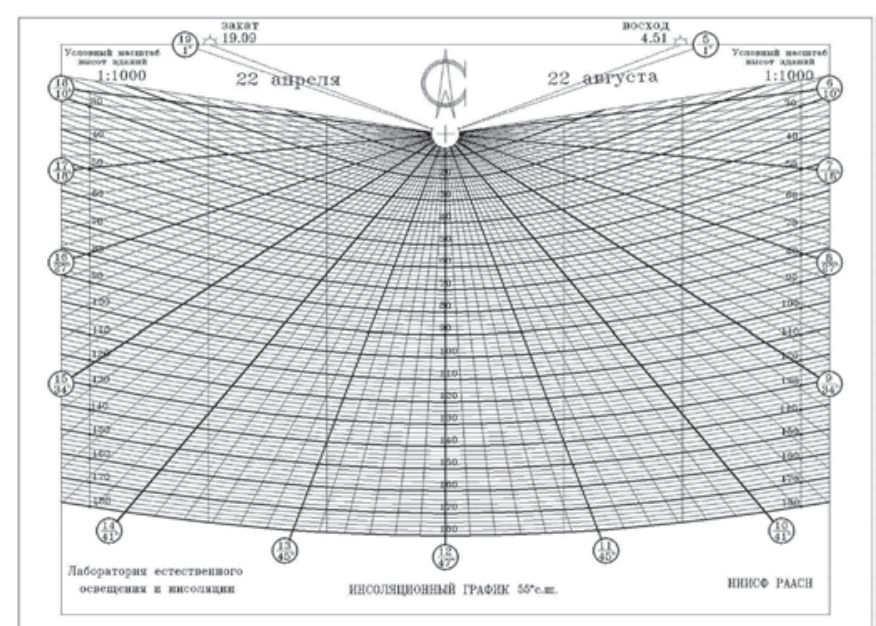

Рис. 1. Инсоляционный график для города Москвы (55 ${ }^{\circ}$ с. щ.) в масштабе 1:1000

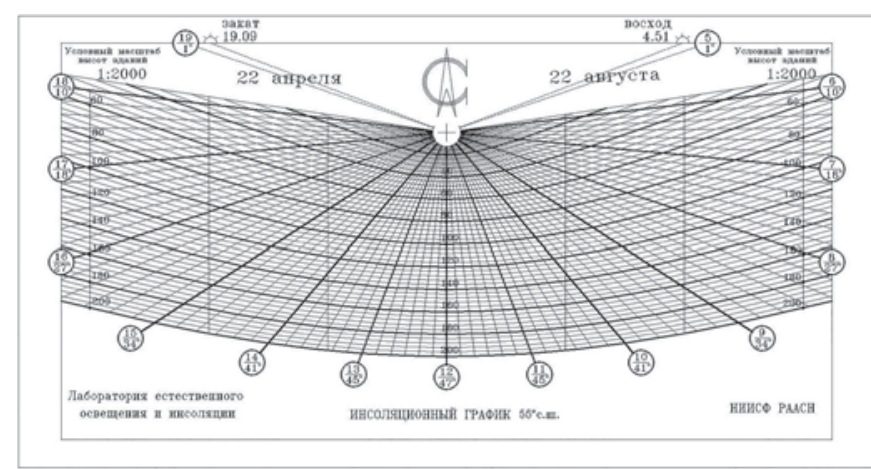

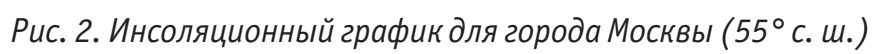
в масштабе 1:2000
В таблице 6 представлены основные графические методы расчёта инсоляции в ведущих странах.

В 2017 году в СанПиН [13] изменился период нормирования инсоляции. Изменение нормируемого периода инсоляции для центральной географической зоны территории России с 22 марта - 22 сентября на 22 апреля - 22 августа повлекло за собой необходимость изменения инсоляционных графиков для центральной географической зоны. В НИИСФ РААСН были разработаны новые графики для центральной географической зоны. Графики для 55-ой северной широте в приложениях В1 и В2 проекта Изменения № 1 ГОСТ Р 57795-2017 [43] приведены на рисунках 1 и 2.

$$
* * *
$$

Рассмотрение текущего состояния нормирования и расчёта продолжительности инсоляции помещений позволило сделать следующие выводы.

1. Естественный ультрафиолет, содержащий УФ-А и УФ-В, поступающий в помещения с солнечными лучами, способствует инактивации вирусов, бактерий и патогенной микрофлоры. В том числе он ограничивает распространение новой пандемии, вызванной вирусами COVID-19. Солнечные лучи оказывают санирующий эффект как на микроорганизмы и микрофлору, находящихся в аэрозольном состоянии в воздухе, так и на микроорганизмы и микрофлору, живущих на поверхностях.

2. Поскольку интенсивность естественного ультрафиолетового излучения максимальна в летние месяцы, в эти месяцы отмечается снижение числа заразившихся гриппом, ОРВИ и коронавирусом. Подъём заболеваний в осенне-зимне-весенний период может быть вызван снижением интенсивности естественного ультрафиолетового излучения.

3. Плотность застройки городов необходимо ограничивать, чтобы они не стали средой для распространения существующих и новых вирусных и бактериальных инфекций по аналогии со средневековыми городами.

4. Продолжительность инсоляции была и остаётся нормируемой и рассчитываемой величиной при строительстве жилых и некоторых общественных зданий и придомовых территорий как в странах Евросоюза и Великобритании, так и в странах азиатского региона - Китае, Японии, Монголии, - а также в странах СНГ и ближнего зарубежья.

5. В 2017 году изменением №1 СанПиН 2.2.1/2.1.1.1076-01 был определён период инсоляции для центральной географической зоны России: 22 апреля - 22 августа (вместо 22 марта - 22 сентября), что потребовало разработки новых инсоляционных графиков для центральной географической зоны.

6. В настоящее время в стадии утверждения находится Изменение №1 ГОСТ Р 57795-2017 «Здания и сооружения. Методы расчёта продолжительности инсоляции», в котором приведены инсоляционные графики для центральной географической зоны России (580 с.ш. - 480 с.ш.) на новый период инсоляции. 


\section{Лumepamypa}

1. Simulated Sunlight Rapidly Inactivates SARS-CoV-2 on Surfaces Shanna Ratnesar-Shumate // S. Ratnesar-Shumate, G. Williams, B. Green [et al.]// The Journal of Infectious Diseases. - 2020. - № 6. - Р. 3-9.

2. Краткая медицинская энциклопедия : в 2-х томах / Под ред. академика РАМН В.И. Покровского. - М. : НПО «Медицинская энциклопедия», «Крон-Пресс», 1994. - Том 1. - 608 с. - С. 271); Том 2. - 544 с. - С. 378.

3. Руководство по медицине. Диагностика и терапия : В 2-х томах / Под ред. Р. Беркоу и Э.Флетчера. - М. : Мир, 1997. - Том 1. - 1045 с. - С. 84.

4. Фокин, С.Г. Обоснование гигиенических требований к световому режиму помещений жилых и общественных зданий в условиях крупного города. Автореф. дис. канд. мед. наук. - М. : МГМА последипломного образования, 2003. - 24 с.

5. Данциг, Н.М. Гигиена освещения и инсоляции зданий и территорий застройки городов / Н.М. Данциг. - М. : БР, 1971.

6. Boubekri, M. Impact of window size and sunlight penetration on office workers' mood and satisfaction. a novel way of assessing sunlight / M. Boubekri, R.B. Hull, L.L Boyer. // Environment and Behavior. - 1991. - Vol. 23. - № 4. - P. 474-493.

7. Darula, S. Sunlight and insolation of building interiors [Электронный ресурс] / S. Darula, J. Christoffersen, M. Malikova // 6th International Building Physics Conference, IBPC 2015; Energy Procedia, 78, 2015, pp. 1245-1250. - Режим доступа: http://www.sciencedirect.com (дата обращения 20.10.2020).

8. Куприянов В.Н., Халикова Ф.Р. Натурные исследования энергетических параметров инсоляции жилых помещений / В.Н. Куприянов, Ф.Р. Халикова // Известия Казанского государственного архитектурно-строительного университета. - 2012. -№ 4. - С. 139-147.

9. Исследование влияния мультифункционального покрытия стекла на спектральное пропускание света / В.Г. Гагарин, Е.В. Коркина, И.А. Шмаров, П.П. Пастушков // Строительство и реконструкция. - 2015. - № 2 (58). - С. 90-95.

10. Гагарин В.Г. Экспериментальные исследования светотехнических параметров оконных стекол / В.Г. Гагарин, Е.В. Коркина // Интеграция, партнёрство и инновации в строительной науке и образовании : Сборник материалов Международной научной конференции / Под редакцией Т.И. Квитка, И.П. Молчанова. - М., 2015.

\section{References}

1. Ratnesar-Shumate S., Williams G., Green B., Krause M., Holland B., Wood S., Bohannon J., Boydston J., Freeburger D., Hooper I., Beck K., Yeager J, Altamura L. A., Biryukov J., Yolitz J., Schuit M., Wahl V., Hevey M., and Dabisc P. Simulated Sunlight Rapidly Inactivates SARS-CoV-2 on Surfaces Shanna RatnesarShumate. In: The Journal of Infectious Diseases, 2020, no. 6, pp. 3-9. (In Engl.)

2. Kratkaya meditsinskaya entsiklopediya $\vee 2-k h$ tomakh [Brief medical encyclopedia in 2 volumes]. V.I. Pokrovskii (ed.).
Moscow, NPO "Meditsinskaya entsiklopediya", "Kron-Press" Publ., 1994, Vol. 1, 608 p., p.271; Vol. 2, 544 p., p. 378. (In Russ.)

3. Rukovodstvo po meditsine. Diagnostika i terapiya. V 2-kh t. [Guide to medicine. Diagnostics and therapy. In 2 vol.]. R. Berkou and E.Fletchera (eds.). Moscow, Mir Publ., 1997, Vol. 1, 1045 p., p. 84. (In Russ.)

4. Fokin S.G. Obosnovanie gigienicheskikh trebovanii k svetovomu rezhimu pomeshchenii zhilykh i obshchestvennykh zdanii v usloviyakh krupnogo goroda [Substantiation of hygienic requirements for the light regime of residential and public buildings in alarge cit]. Author's abstract. dis. Cand. honey. sciences. Moscow, MGMA of postgraduate education, 2003, 24 p., p.7. (In Russ.)

5. Dantsig N. M. Gigiena osveshcheniya i insolyatsii zdanii i territorii zastroiki gorodov [Hygiene oflighting and insolation of buildings and urban development territories]. Moscow, BRE Publ., 1971. (In Russ.)

6. Boubekri M., Hull R.B., Boyer L.L. Impact of window size and sunlight penetration on office workers' mood and satisfaction. A novel way of assessing sunlight. In: Environment and Behavior, 1991, Vol. 23, no. 4, pp. 474-493. (In Engl.)

7. S. Darula, J. Christoffersen, M. Malikova Sunlight and insolation of building interiors. In: 6th International Building Physics Conference, IBPC 2015. Energy Procedia, 78, 2015, pp. 1245-1250. Access mode: http://www.sciencedirect.com (accessed 10.20.2020). (In Engl.)

8. Kupriyanov V.N., Khalikova F.R. Naturnye issledovaniya energeticheskikh parametrov insolyatsii zhilykh pomeshchenii [Field studies of energy parameters of insolation of residential premises]. In: Izvestiya Kazanskogo gosudarstvennogo arkhitekturno-stroitel'nogo universiteta [News of the Kazan State University of Architecture and Engineering], 2012, no. 4, pp. 139-147. (In Russ., abstr. In Engl.)

9. Gagarin V.G., Korkina E.V., Shmarov I.A., Pastushkov P.P. Issledovanie vliyaniya mul'tifunktsional'nogo pokrytiya stekla na spektral'noe propuskanie sveta [Investigation of the effect of multifunctional glass coatings on the spectral transmission oflight]. In: Stroitel'stvo i rekonstruktsiya [Construction and reconstruction], 2015, no. 2 (58), pp. 90-95. (In Russ., abstr. In Engl.)

10. Gagarin V.G., Korkina E.V. Eksperimental'nye issledovaniya svetotekhnicheskikh parametrov okonnykh stekol [Experimental studies of the lighting parameters of window glass]. In : Integratsiya, partnerstvo $i$ innovatsii $v$ stroitel'noi nauke i obrazovanii : Sbornik materialov Mezhdunarodnoi nauchnoi konferentsii [Integration, partnership and innovation in building science and education. Collection of materials of the International Scientific Conference] . T.I. Kvitka, I.P. Molchanov (eds.)]. Moscow, 2015.

Список использованных нормативных документов и исТочников

11. ЕСЕ/НВР/81. Компендиум Европейской экономической комиссии (ЕЭК), включающий образцы положений для стро- 
ительных правил. - Нью-Йорк: Организация Объединенных Наций, 1992. - 105 с.

12. СанПиН 2.2.1/2.1.1.1076-01 «Гигиенические требования к инсоляции и солнцезащите помещений жилых и общественных зданий и территорий». - М. : Федеральный центр Госсанэпиднадзора Минздрава России, 2002. - 15 с.

13. Изменения № 1 в санитарные правила и нормы СанПиН 2.2.1/2.1.1.1076-01 «Гигиенические требования к инсоляции и солнцезащите помещений жилых и общественных зданий и территорий. Постановление главного санитарного врача от 10.04.2017. - № 47. - 3 с. // КонсультантПлюс. - Режим доступа: https://base.garant.ru/12124767/ (дата обращения 11.11.2020).

14. ЕН 13037:2018. «Естественное освещение» (EN 13037:2018 «Daylighting». - 56 p.

15. DIN 5034-1: 2011 Естественный свет в помещениях. Часть 1: Общие требования. (DIN 5034-1: 2011 Tageslicht in Innenraumen. Teil 1: Allgemeine Anforderungen. - Berlin, Deutsches Institut für Normung e.V.), 2011. - $19 \mathrm{~s}$

16. DIN 5034-2: 1985 Естественный свет в помещениях. Основы - (DIN 5034-2: 1985 Tageslicht in Innenräumen. Grundlagen - Berlin, Deutsches Institut für Normung e.V.), 1985 - $13 \mathrm{~s}$.

17. BS 8206-2:2008 «0свещение зданий» - Часть 2. Строительные нормы и правила естественного освещения. (BS 8206-2:2008. Lighting for buildings. Part 2) - London, BSI, 2008.

18. Градостроительный кодекс Франции R 111-17 (Art R 111-17 Town planning code).

19. Декрет Франции 73-1023 - 8 февраля 1973 (Decret 731023 - 8th of February 1973).

20. Собрание уставов Национального совета по жилищному строительству и планированию // Solklar (Швеция) (Boverkets författningssamling - publication Solklart), 1991.

21. Сборник законодательных актов Национального совета по жилищному хозяйству, строительству и планированию. Постановление о строительстве (Швеция) (Boverkets författningssamling - building regulation BFS, 2014:3; H255).

22. Постановление № 268/2009 о технических требованиях для зданий (Чехия) (Regulation No. 268/2009 about technical requirements for buildings.

23. Стандарт Чехии ČSN 73 4301:2004. Жилые здания. (ČSN 73 4301:2004. Obytné budovy).

24. Постановление № 259/2008 Министерства здравоохранения Словакии (Regulation No. 259/2008 of the Ministry of Health).

25. Постановление № 532/2002 Министерства охраны окружающей среды Словакии (Regulation No. 532/2002 of the Ministry of Environment).

26. Стандарт Словакии STN 73 4301:2005 Жилые здания (Standard STN 73 4301:2005 Buildings for dwelling).

27. Правила минимальных технических требований при строительстве жилых домов - 2005. (Rules on minimum technical requirements for the construction of residential buildings - 2005).

28. TSG-1-004:2010 Техническое руководство. Эффективное использование энергии. Муниципальные правила. (TSG-1-004:2010 Technical guideline. Efficient use of energy.

29. Постановление № 620/2002 Министерства инфраструктуры Польши по техническим требованиям, которым должны удовлетворять здания и их размещение при строительстве (Regulation No. 620/2002 of the Ministry of Infrastructure on the technical requirements to be met by buildings and their placement.).

30. RT I: 2002 Закон о строительстве (Строительный кодекс)- (Ehitusseadus (Building Code).

31. Стандарт EVS 894:2008+A1:2010. Освещение жилых и офисных помещений (Standard: EVS 894:2008+A1:2010. Lighting for residential and office premises).

32. Технический стандарт анализа инсоляции зданий провинции Хубэй (Китай). (湖北省建筑日照分析技术规范).

33. Технический анализ инсоляции городских строительных проектов провинции Чжэцзян (Китай). (浙江省城市建设工程日照分析技术规程).

34. Технический анализ инсоляции городского строительства города Сюйчан в провинции Хэнань (Китайская народная республика) (许昌市区建设工程日照分析技术规程).

35. Технический анализ инсоляции жилого строительства города Чанчунь провинции Гирин. (Китайская народная республика) (浙江省城市建设工程日照分析技术规程).

36. Технический анализ инсоляции проектов строительства города Джанцзяган провинции Цзенсу (Китайская народная республика). (张家港市建设项目日照分析技术规范).

37. БНбД 23-04-07 «0беспечение инсоляцией помещений жилых и общественных зданий и территорий». (БНбД 23-0407 «0рон сууц, олон нийтийн барилга, сууцны барилгажилтын бусийн нарны тусгалын (ээвэрлэлтийн) хангамж»). - Улаанбаатар хот, 2007 он.

38. Санитарные правила и нормы. Гигиенические требования обеспечения инсоляцией жилых и общественных зданий и территорий жилой застройки. Постановление Министерства здравоохранения Республики Беларусь 28 апреля 2008 № 80 - Минск. -10 с.

39. Санитарно-эпидемиологические требования к административным и жилым зданиям. Приказ Министра здравоохранения Республики Казахстан от 26 октября 2018 года № ҚР ДСМ-29. Зарегистрирован в Министерстве юстиции Республики Казахстан 23 ноября 2018 года № 17769

40. Государственные санитарные правила планирования и застройки населённых пунктов. Утверждены приказом Министерства здравоохранения Украины от 19 июня 1996 г. № 173 (Державні санітарні правила планування та забудови населених пунктів, Затверджено наказом Міністерства охорони здоров'я України від 19 червня 1996 р. № 173).

41. ДСТУ-Н Б В.2.2-27-2010. Государственный стандарт Украины. «Руководство по расчёту инсоляции объектов 
гражданского назначения». (Будинки і споруди. Настанова 3 розрахунку інсоляції об'єктів цивільного призначения [Текст]: ДСтУ Н Б В.2.2-27:2010.) [Дата введения 2011-01-01] / Минрегіонбуд України. - Киев : Укрархбудінформ, 2010. - 81 с.
42. ГОСТ Р 57795-2017 «Здания и сооружения. Методы расчёта продолжительности инсоляции. М. : Стандартинформ, 2017.

43. Проект Изменения №1 ГОСТ Р 57795-2017 «Здания и сооружения. Методы расчёта продолжительности инсоляции. - НИИСФ РААСН: 2020. - 7 c.

Шмаров Игорь Александрович (Москва). Кандидат технических наук. Главный научный сотрудник ФГБУ «Научно-исследовательский институт строительной физики Российской академии архитектуры и строительных наук» (127238, Москва, Локомотивный проезд, 21. НИИСФ РААСН). Эл.почта: shmarovigor@yandex.ru.

Земцов Виктор Андреевич (Москва). Кандидат технических наук. Главный научный сотрудник ФГБУ «Научно-исследовательский институт строительной физики Российской академии архитектуры и строительных наук» (127238, Москва, Локомотивный проезд, 21. НИИСФ РААСН). Эл.почта: ins-es@yandex.ru.

Гуськов Андрей Сергеевич (Москва). Кандидат медицинских наук. Заместитель начальника Управления санитарного надзора Роспотребнадзора (127994, Москва, Вадковский пер., 18).Эл.почта:guskov_as@gsen.ru.

Бражникова Людмила Вадимовна (Москва). Ведущий научный сотрудник ФГБУ «Научно-исследовательский институт строительной физики Российской академии архитектуры и строительных наук» (127238, Москва, Локомотивный проезд, 21. НИИСФ PAACH). Эл.почта:Lab22niisf@yandex.ru.

Shmarov Igor A. (Moscow). Candidate of Technical Sciences (Engineering). Chief Researcher at the Scientific-Research Institute of Building Physics of the Russian Academy of Architecture and Construction Sciences (21 Lokomotivny proezd, Moscow, 127238. NIISF RAACS).E-mail: shmarovigor@yandex.ru.

Zemtsov Viktor A. (Moscow). Candidate of Technical Sciences (Engineering). Chief Researcher at the Scientific-Research Institute of Building Physics of the Russian Academy of Architecture and Construction Sciences (21 Lokomotivny proezd, Moscow, 127238. NIISF RAACS).E-mail: ins-es@yandex.ru.

Guskov Andrey S. (Moscow). Candidate of Medical Sciences. Deputy Head of the Sanitary Inspection Department of the Federal Service for Supervision of Consumer Protection and Welfare (18 Vadkovsky per., Moscow, 127994. Rospotrebnadzor). E-mail: guskov_as@gsen.ru.

Brazhnikova Lyudmila V. (Moscow). Leading Researcher at the Scientific-Research Institute of Building Physics of the Russian Academy of Architecture and Construction Sciences (21 Lokomotivny proezd, Moscow, 127238. NIISF RAACS).E-mail:Lab22niisf@ yandex.ru 